\title{
In situ quantification of Tripneustes gratilla grazing and its effects on three co-occurring tropical seagrass species
}

\author{
Jan Arie Vonk ${ }^{1,2, *}$, Marjolein H. J. Pijnappels ${ }^{1}$, Johan Stapel ${ }^{1}$ \\ ${ }^{1}$ Department of Environmental Science, Institute for Wetland and Water Research, Faculty of Science, \\ Radboud University Nijmegen, PO Box 9010, 6500 GL Nijmegen, The Netherlands \\ ${ }^{2}$ Present address: Laboratory for Ecological Risk Assessment, National Institute for Public Health and the Environment \\ (RIVM), PO Box 1, 1370 BA Bilthoven, The Netherlands
}

\begin{abstract}
We studied sea urchin Tripneustes gratilla herbivory in a meadow of co-occurring seagrass species Thalassia hemprichii (climax species), Halodule uninervis and Cymodocea rotundata (colonizing species) to determine effects of sea urchins on seagrass biomass and species composition, to quantify herbivory rate and to determine the role of urchins in the nitrogen (N) cycle. In a 2 mo enclosure experiment in Sulawesi, Indonesia, we increased T. gratilla density and measured seagrass shoot density and aboveground biomass. Belowground biomass was determined at the start and end of the experiment and leaf production at the end. Carbon (C) and N concentrations were measured in plant material. Increased T. gratilla grazing did not influence seagrass shoot density or leaf production. Herbivory had a negative impact on the biomass per shoot for all species, but only $H$. uninervis and $C$. rotundata aboveground biomass declined significantly. The proportion of aboveground biomass made up by T. hemprichii increased significantly from 37 to $68 \%$ of the total seagrass biomass, while $C$. rotundata biomass declined significantly from 25 to $11 \%$ of the total biomass. No significant decline occurred in $H$. uninervis (from 38 to $21 \%$ ). Over the experiment, T. gratilla grazing significantly reduced the aboveground biomass by $74 \%$, but had no effect on belowground biomass. Grazing caused an increase in leaf $\mathrm{N}$ concentration for $H$. uninervis and $C$. rotundata. The calculated mean \pm SE $N$ intake rate was $15.9 \pm 1.1 \mathrm{mg} \mathrm{N}$ urchin $^{-1} \mathrm{~d}^{-1}$. Total consumption by T. gratilla in the meadow at an average urchin density of $1.55 \pm 0.07$ urchins $\mathrm{m}^{-2}$ was calculated to be $1.28 \mathrm{~g}$ dry weight $\mathrm{m}^{-2} \mathrm{~d}^{-1}$, corresponding to $26 \%$ of the net aboveground seagrass production. We conclude that T. gratilla consumes a considerable amount of the leaf production and even influences species composition in tropical seagrass meadows. T. gratilla grazing may play a role in conserving $\mathrm{N}$ within the meadow and create short-circuits in the N cycling of seagrass leaf material.
\end{abstract}

KEY WORDS: Herbivory · Species composition · Tropical seagrass · Sea urchin · Tripneustes gratilla • Indonesia

Resale or republication not permitted without written consent of the publisher

\section{INTRODUCTION}

Seagrass meadows in the Indo-Pacific often consist of co-occurring seagrass species that maintain a high rate of leaf production year-round (Hemminga \& Duarte 2000). Part of this leaf production directly enters the detritus pathway, while another part is consumed by herbivores or exported (Duarte \& Cebrian 1996, Cebrian \& Duarte 1998). Historically, turtles and dugongs were the main seagrass herbivores, but their numbers have declined greatly (Jackson et al. 2001). Currently, the most abundant herbivores on seagrasses are fishes, crustaceans and sea urchins (Alcoverro \& Mariani 2004, Goecker et al. 2005, Valentine \& Duffy 2006)

In the tropical Indo-Pacific region, sea urchins are widely present in seagrass meadows (Klumpp et al. 1993, Alcoverro \& Mariani 2002). Sea urchin grazing 
affects aboveground biomass, leaf production, shoot density and cover of seagrasses (Keller 1983, Valentine \& Heck 1991, Valentine et al. 1997, Alcoverro \& Mariani 2004). Leaf herbivory is highly variable among different seagrass species (Cebrian \& Duarte 1998); grazing preferences of sea urchins on different seagrass species are poorly understood for the multi-species meadows of the Indo-Pacific (Vaitilingon et al. 2003) where climax and colonizing grass species co-occur. Sea urchin herbivory may play a role in maintaining seagrass biodiversity in these meadows. Other important effects are physical environmental factors (Koch et al. 2006) and nutrients (Hemminga \& Duarte 2000).

Few in situ studies have been performed to quantify sea urchin grazing in the Indo-Pacific (Valentine \& Duffy 2006). The sea urchin Tripneustes gratilla occurs widely in shallow waters and grazes predominantly on seagrasses (Klumpp et al. 1993, Lawrence \& Agatsuma 2001). By measuring herbivory rate and the nitrogen (N) content of the leaves, $\mathrm{N}$ intake rates of $T$. gratilla and the removal of $\mathrm{N}$ from the seagrasses by grazing can be estimated (Valentine \& Duffy 2006). Not all seagrass material ingested by sea urchins is digested efficiently (Lawrence \& Klinger 2001) and finely-fragmented undigested material is voided from the digestive tract (Koike et al. 1987). Sea urchin grazing therefore influences the $\mathrm{N}$ cycling of seagrass meadows in different ways.

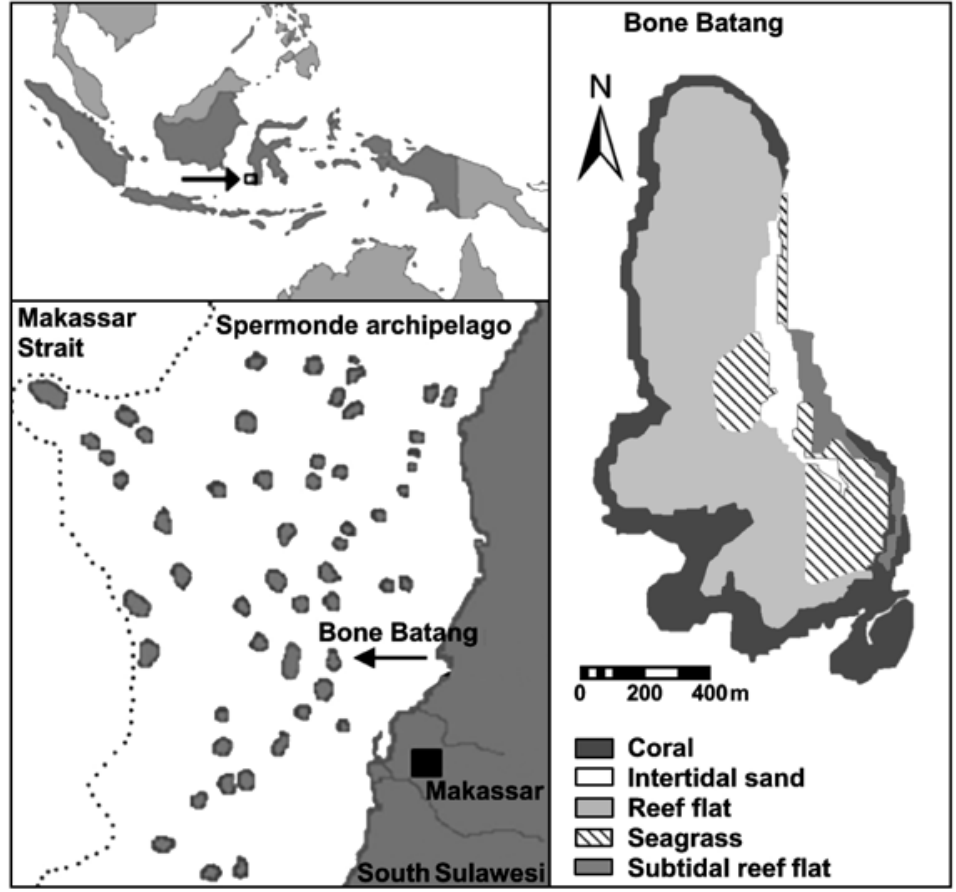

Fig. 1. Study area, showing the location and the islands of the Spermonde Archipelago along the west coast of South Sulawesi (dotted line: shelf edge $200 \mathrm{~m})$, overview of the island Bone Batang $\left(5^{\circ} 01^{\prime} 00^{\prime \prime} \mathrm{S}\right.$, $119^{\circ} 19^{\prime} 30^{\prime \prime} \mathrm{E}$ ) and seagrass meadows
We propose that sea urchin grazing influences seagrass biomass, density, production and species composition in tropical mixed-species seagrass meadows. We investigated the effects of Tripneustes gratilla grazing on above- and belowground biomass, tissue $\mathrm{N}$ and carbon (C) concentrations, density, leaf production and species composition of a meadows consisting of the cooccurring seagrass species Thalassia hemprichii (climax species), Halodule uninervis and Cymodocea rotundata (colonizing species). We quantified grazing by $T$. gratilla on the seagrasses and determined the role of sea urchin grazing in $\mathrm{N}$ cycling within a tropical oligotrophic seagrass meadow. For this purpose, the density of the sea urchins $T$. gratilla was artificially increased in situ in $1 \times 1 \mathrm{~m}$ enclosures deployed in the seagrass meadow.

\section{MATERIALS AND METHODS}

Study site. The experiments were carried out on Bone Batang $\left(5^{\circ} 01^{\prime} \mathrm{S}, 119^{\circ} 19^{\prime} 30^{\prime \prime} \mathrm{E}\right)$, an uninhabited coral island in the Spermonde Archipelago, South Sulawesi, Indonesia, located $15 \mathrm{~km}$ offshore and $2 \mathrm{~km}$ north of Barang Lompo (Fig. 1). The island consists of an intertidal sandbank with a surrounding reef flat and barrier reef. The reef flat consists of coarse carbonate sand and coral rubble and is covered by an extensive seagrass meadow consisting of the co-occurring Thalassia hemprichii, Halodule uninervis and Cymodocea rotundata. Halophila ovalis was found in low densities and accounted for $<1 \%$ of the aboveground biomass.

Urchin densities. Three permanent transects of $15 \times 1 \mathrm{~m}$ were pegged out to estimate the densities of Tripneustes gratilla in the seagrass meadow. During daytime, the number of urchins present in each of 15 quadrats of $1 \mathrm{~m}^{2}$ was counted on 11 occasions over the period of 1 yr. On 5 occasions, we measured size of each counted sea urchin.

Grazing experiments. Four replicate enclosures $(1 \times 2 \mathrm{~m})$ were constructed at an experimental site in the seagrass bed with a well developed mixture of the 3 co-occurring seagrass species. Each enclosure consisted of two $1 \times 1 \mathrm{~m}$ compartments $\sim 40 \mathrm{~cm}$ high with different grazing treatments. All visible (i.e. $>10 \mathrm{~mm}$ ) macrobenthos was first removed by hand from the enclosures. The grazing treatments were (1) no grazers added (control) and (2) sea urchins added (Tripneustes treatment). Five $T$. gratilla specimens with an average test diameter of $7.1 \mathrm{~cm}$ were introduced in the Tripneustes 
treatment. We used a density of 5 sea urchins $\mathrm{m}^{-2}$ (about thrice the average density) deliberately to generate a measurable impact of $T$. gratilla grazing on the seagrass biomass, but made sure that density stayed within the natural range found in this area, which is $\leq 7$ urchins $\mathrm{m}^{-2}$.

The enclosures were constructed of zinc screen with $30 \mathrm{~mm}$ square mesh. The zinc screen was supported by wooden poles placed on the outside of the enclosures and completely covered the enclosures. The screen was not buried in the sediment (to prevent damage to the rhizomes). The sites chosen for the deployment of enclosures were about $30 \mathrm{~cm}$ below extreme low water (ELW). The experiment lasted for $58 \mathrm{~d}$ and was performed during the dry season (May to July 2005) with little or no environmental disturbance (e.g. wind, wave action) and stable seagrass growth conditions (Erftemeijer \& Herman 1994). Since the enclosures had a wide mesh, were placed at shallow depth in clear offshore waters and were cleaned of epiphytes every week, we assume light limitation did not influence the experiment.

Sample collection. We used a sample collection method slightly modified from Valentine \& Heck (1991). Every $10 \mathrm{~d}$, three $0.01 \mathrm{~m}^{2}$ square quadrats (subsample) within each treatment were sampled according to a predetermined random sampling design applied in the same way to each treatment to assure quadrats were only sampled once during the whole experiment (Fig. 2). The seagrass leaves in the quadrats were cut off at sediment surface level using scraper blades. Total number of shoots per species was counted in each quadrat. Sampled leaves were cleaned of epiphytes using scraper blades, separated by species, and biomass dry weight (DW) was determined after oven drying $\left(70^{\circ} \mathrm{C}, 48 \mathrm{~h}\right)$. Data of the 3

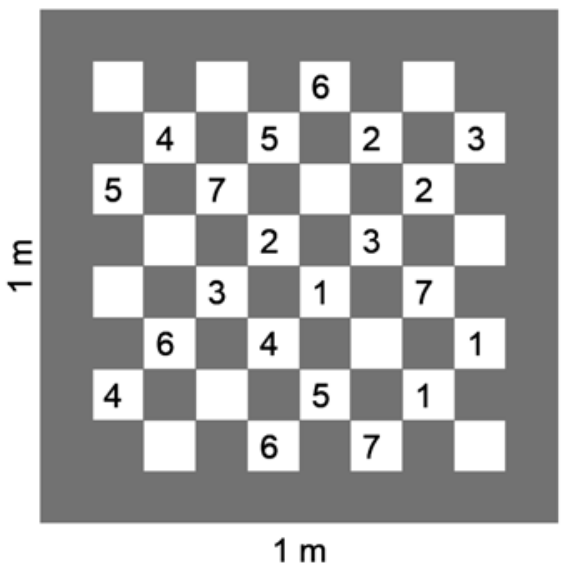

Fig. 2. Schematic overview of the sampling quadrats $(0.1 \times$ $0.1 \mathrm{~m}$ ) harvested in each treatment. Quadrats $1,2,3,4,5,6$ and 7 were harvested on Days 0, 9, 19, 29, 38, 48 and 58, respectively quadrats harvested from each treatment at 1 day were pooled together for statistical analysis. Belowground biomasses in the Tripneustes treatments were sampled at the start and end of the experiment using 3 cores (diameter $6 \mathrm{~cm}$, depth $15 \mathrm{~cm}$ ). Belowground plant material was washed free from sediment, divided into roots and rhizomes and treated like the aboveground samples. $\mathrm{N}$ and $\mathrm{C}$ concentrations (\% DW) in aboveground and belowground tissues were determined using a Carlo Erba NA 1500 elemental analyzer.

Leaf production. Leaf production was measured at the end of the experiment. Four replicate samples of 10 shoots for each species were marked in each treatment using the leaf marking technique described by Short \& Duarte (2001). The marked shoots were harvested $17 \mathrm{~d}$ after leaf marking, divided into newly produced and old material, and treated like aboveground samples. Leaf production (g DW shoot ${ }^{-1} \mathrm{~d}^{-1}$ ) was calculated as the amount of newly produced leaf material divided by the product of time (17 d) and the number of shoots (10), resulting in 4 average values per treatment and species.

Leaf loss. We estimated the amount of seagrass production consumed by sea urchins using a mass balance equation that partitions plant production into changes in biomass and leaf loss rate (modified from Valentine \& Heck 2001): $L=\mathrm{NAPP}-\Delta B$; where $L$ is the leaf loss rate between 2 sampling dates, NAPP is the net aboveground primary production, and $\Delta B$ is the change in aboveground biomass. Average NAPP was calculated at each sampling date by multiplying the leaf production per shoot by the measured shoot densities. The leaf loss rate $(L)$ consisted of the sum of sea urchin herbivory rate $(H)$ and the export rate of leaves $(E)$.

Statistical analysis. Before statistical analyses, seagrass density data $(n+0.5)$ were normalized by square root transformation. Shoot and leaf biomass were logtransformed (Sokal \& Rohlf 1995). Transformed data were tested for equality of variances using Levene's test. All measured parameters (shoot density, biomass per shoot and aboveground biomass) were analyzed using MANOVA with grazing and time as fixed factors. Significant effect for any of the parameters was followed up by individual independent $t$-test comparison on these parameters for the start and end of the experiment. The change in percentage of total aboveground biomass per species was compared between Day 0 and Day 58 in the Tripneustes treatment. The leaf growth rate, $\mathrm{C}$ and $\mathrm{N}$ concentrations and belowground biomass were analyzed using independent $t$-tests. Relative aboveground biomasses per seagrass species at the start and end of the experiment were compared in the Tripneustes enclosures. All statistical analyses were performed in SPSS 14.0. Values in the text are given as mean $\pm \mathrm{SE}$ and $\mathrm{p}<0.05$ was considered significant. 

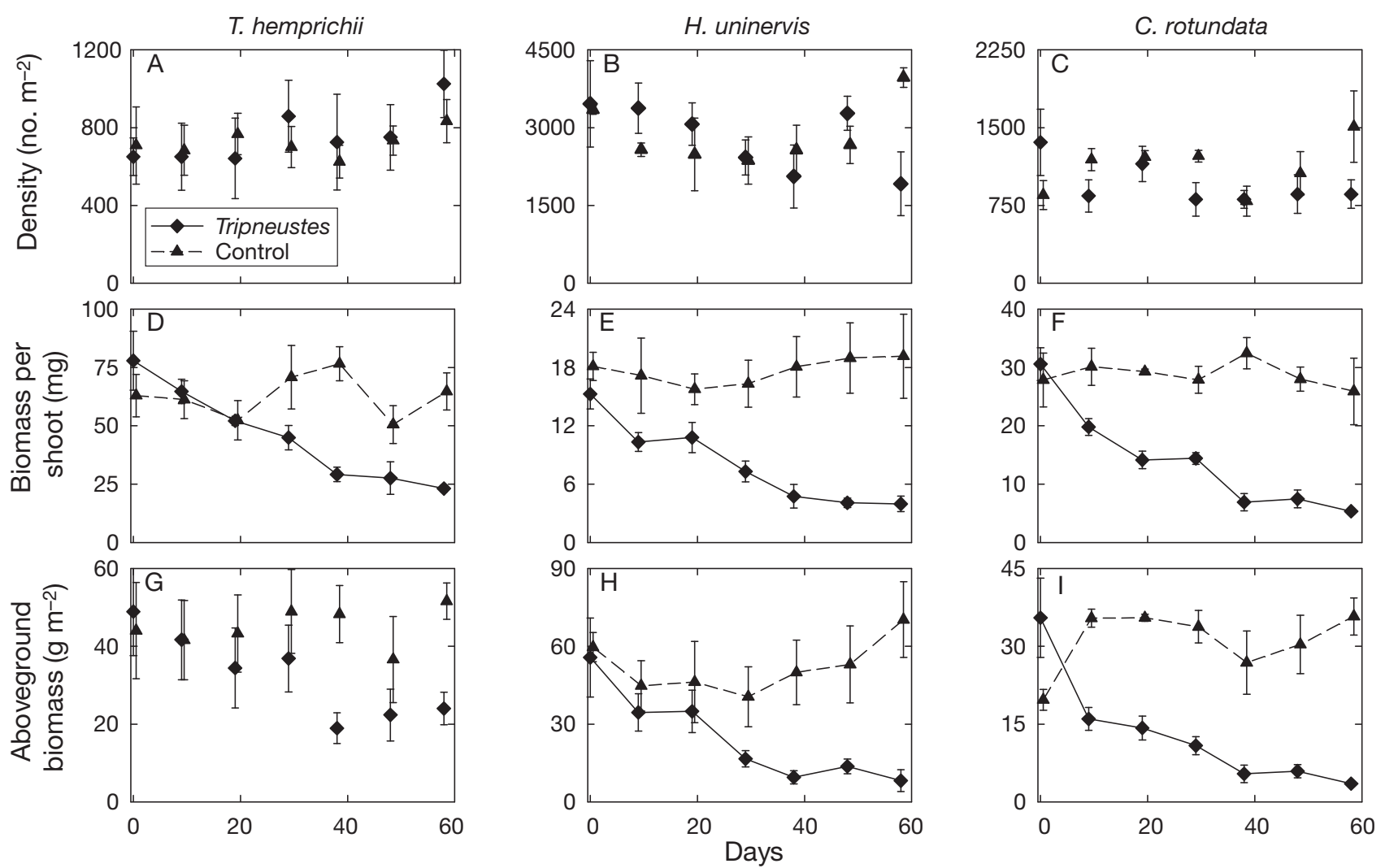

Fig. 3. Thalassia hemprichii, Halodule uninervis, and Cymodocea rotundata. Mean $\pm \mathrm{SE}(\mathrm{n}=4)$ seagrass density, shoot biomass and aboveground biomass in the control and Tripneustes treatment for the different species during the experiment. Symbols connected by lines indicate significant differences between control and treatment plots (MANOVA, Table 1)

\section{RESULTS}

\section{Urchin densities}

Tripneustes gratilla density in the seagrass meadow was on average (mean \pm SE) $1.55 \pm 0.07$ urchins $\mathrm{m}^{-2}$ (range 0 to 7 urchins $\mathrm{m}^{-2}$ ). No trend in urchin density was observed over the year. The average test diameter was $6.8 \pm 0.1 \mathrm{~cm}$ (range 1.5 to $11.0 \mathrm{~cm}$ ). All T. gratilla individuals were solitary and often covered with seagrass leaves, detritus and other material.

\section{Grazing of seagrass shoots}

The responses of seagrass to grazing by Tripneustes gratilla during the experiment were measured for shoot density, biomass per shoot and aboveground biomass and tested using MANOVA (Fig. 3, Table 1). No significant changes in shoot density were measured in the treatments during the experiment (Fig. 3A-C). T. gratilla grazing resulted in a significant decline of the biomass per shoot for all species over $58 \mathrm{~d}$ (all species $\mathrm{p}<0.01$ ), while in the control treatment this was stable (Fig. 3D-F). Grazing during $58 \mathrm{~d}$ also resulted in a significant decline of aboveground biomass for Halodule uninervis $(\mathrm{p}=0.012$ ) (Fig. $3 \mathrm{H})$, Cymodocea rotundata ( $p<0.001$ ) (Fig. 3I), and total aboveground biomass ( $p<0.001$ ) (Fig. 4), but not for Thalassia hemprichii (Fig. 3G). In the Tripneustes treatment, the aboveground biomass of $T$. hemprichii relative to $H$. uninervis and $C$. rotundata increased significantly ( $\mathrm{p}=$ 0.042 ) from 37 to $68 \%$ of the total biomass, C. rotundata aboveground biomass declined significantly (from 25 to $11 \%$ ) relative to the other 2 species $(p=0.025)$, while relative $H$. uninervis biomass did not change significantly (Table 2) due to grazing over $58 \mathrm{~d}$. In the control treatments, no significant change in total aboveground biomass was measured. In the Tripneustes treatments, the total aboveground seagrass biomass declined sharply (74\%) during the first $38 \mathrm{~d}$ and remained constant until the end of the experiment (Fig. 4). At the end of the experiment, the N concentrations in aboveground biomass were significantly higher in the Tripneustes grazed treatments than in controls for $H$. uninervis $\left(t_{14}=-8.81, \mathrm{p}<0.001\right)$ and $C$. 
Table 1. Thalassia hemprichii, Halodule uninervis, and Cymodocea rotundata. MANOVA (Wilk's lambda) of seagrass responses measured as density (shoots $\left.\mathrm{m}^{-2}\right)$, biomass per shoot $\left(\mathrm{mg} \mathrm{shoot}^{-1}\right)$ and aboveground biomass $\left(\mathrm{g} \mathrm{m}^{-2}\right)$. Grazing and time were taken as fixed factors (grazing $\mathrm{df}=1$, time and grazing $\times$ time $\mathrm{df}=6$, error $\mathrm{df}=41$, and total $\mathrm{df}=56$ ). Bold values denote significant effects $(p<0.05)$. Data were transformed before analyses to ensure homogeneity of variances (see 'Materials and methods-Statistical analysis')

\begin{tabular}{|c|c|c|c|c|c|c|c|c|}
\hline \multirow[t]{2}{*}{ Response } & \multirow{2}{*}{$\begin{array}{c}\mathrm{R}^{2} \\
\text { (Adj) }\end{array}$} & \multirow{2}{*}{$\begin{array}{c}\text { Error } \\
\text { MS }\end{array}$} & \multicolumn{2}{|c|}{ Grazing } & \multicolumn{2}{|c|}{ Time } & \multicolumn{2}{|c|}{ Grazing $\times$ Time } \\
\hline & & & MS & $\mathrm{p}$ & MS & $\mathrm{p}$ & MS & $\mathrm{p}$ \\
\hline \multicolumn{9}{|l|}{ Density } \\
\hline T. hemprichii & -0.142 & 33.307 & 0.704 & 0.885 & 24.773 & 0.618 & 9.316 & 0.943 \\
\hline H. uninervis & 0.125 & 86.632 & 14.868 & 0.681 & 103.224 & 0.329 & 195.481 & 0.056 \\
\hline C. rotundata & 0.113 & 28.193 & 84.998 & 0.090 & 27.868 & 0.445 & 51.874 & 0.114 \\
\hline \multicolumn{9}{|c|}{ Biomass per shoot } \\
\hline T. hemprichii & 0.611 & 0.015 & 0.411 & $<0.001$ & 0.088 & $<0.001$ & 0.097 & $<0.001$ \\
\hline H. uninervis & 0.684 & 0.027 & 2.164 & $<0.001$ & 0.111 & 0.003 & 0.127 & 0.001 \\
\hline C. rotundata & 0.870 & 0.010 & 2.065 & $<0.001$ & 0.164 & $<0.001$ & 0.155 & $<0.001$ \\
\hline \multicolumn{9}{|c|}{ Aboveground biomass } \\
\hline T. hemprichii & 0.093 & 0.061 & 0.447 & 0.010 & 0.055 & 0.497 & 0.059 & 0.456 \\
\hline H. uninervis & 0.541 & 0.071 & 2.556 & $<0.001$ & 0.214 & 0.015 & 0.278 & 0.003 \\
\hline C. rotundata & 0.851 & 0.020 & 3.514 & $<0.001$ & 0.202 & $<0.001$ & 0.312 & $<0.001$ \\
\hline Total & 0.819 & 0.011 & 1.440 & $<0.001$ & 0.098 & $<0.001$ & 0.137 & $<0.001$ \\
\hline
\end{tabular}

Table 2. Thalassia hemprichii, Halodule uninervis, and $\mathrm{Cy}$ modocea rotundata. Mean \pm SE percentage of total aboveground biomass per species in the Tripneustes treatment at the start and end of the experiment. Significant differences (different superscripts) are bold (paired $t$-test, $\mathrm{n}=4$ )

\begin{tabular}{|lcrrr|}
\hline Taxon & \multicolumn{3}{c}{$\begin{array}{c}\text { \% aboveground biomass } \\
\mathrm{t}=0\end{array}$} & \multicolumn{2}{c|}{ Paired $t=58$} & \multicolumn{1}{c|}{$t_{3}$} & $\mathrm{p}$ \\
\hline T. hemprichii & $36.6^{\mathrm{a}} \pm 10.7$ & $67.9^{\mathrm{b}} \pm 8.5$ & -3.42 & $\mathbf{0 . 0 4 2}$ \\
H. uninervis & $37.8 \pm 9.1$ & $21.4 \pm 8.1$ & 2.50 & 0.088 \\
C. rotundata & $25.5^{\mathrm{a}} \pm 5.0$ & $10.7^{\mathrm{b}} \pm 2.5$ & 4.18 & $\mathbf{0 . 0 2 5}$ \\
\hline
\end{tabular}

rotundata $\left(t_{8}=-7.73, \mathrm{p}<0.001\right)$, but not for $T$. hemprichii (Table 3 ). The aboveground $C$ concentration was equal in treatments and controls for all species.

\section{Belowground}

In the Tripneustes treatment, total rhizome biomasses were (mean $\pm \mathrm{SE}$ ) $553 \pm 48$ and $408 \pm 42 \mathrm{~g} \mathrm{DW}$ $\mathrm{m}^{-2}$ at the start and end of the 2 mo grazing period, respectively (no significant decline). Also, none of the individual seagrass species showed a significant decline in rhizome biomass. Root biomass was $210 \pm 15 \mathrm{~g}$ DW $\mathrm{m}^{-2}$ and did not change significantly during the 2 mo grazing experiment. The $\mathrm{N}$ concentrations of the rhizomes did not change and were on average $0.84 \pm$ $0.06 \%, 0.92 \pm 0.05 \%$ and $0.63 \pm 0.04 \%$ for Thalassia hemprichii, Halodule uninervis and Cymodocea rotundata, respectively. Over the experimental period, the $\mathrm{C}$ concentration in $H$. uninervis rhizomes declined signif-

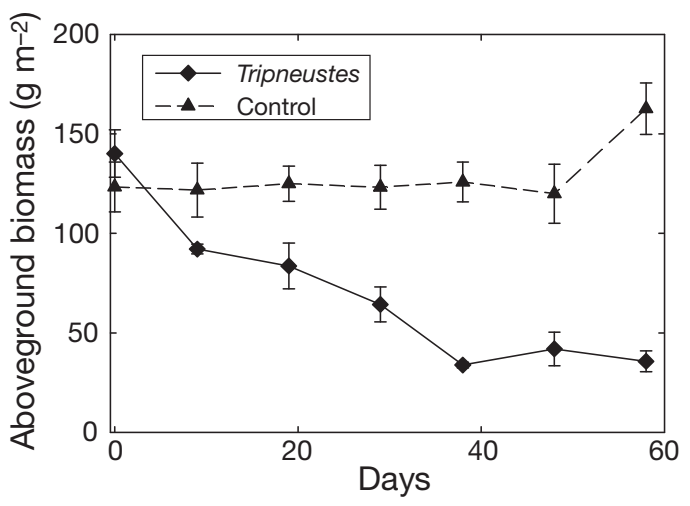

Fig. 4. Mean \pm SE $(n=4)$ aboveground seagrass biomass in the control and Tripneustes treatment through $58 \mathrm{~d}$

icantly from $37.5 \pm 0.6$ to $35.8 \pm 0.4 \%\left(t_{6}=2.47, \mathrm{p}=\right.$ 0.048 ), but no significant change was observed for $T$. hemprichii (average $35.7 \pm 0.3 \%$ ) and C. rotundata (average $36.8 \pm 0.9 \%$ ).

\section{Leaf production and loss}

Leaf production per shoot was highest for Thalassia hemprichii, intermediate for Cymodocea rotundata, and lowest for Halodule uninervis. Leaf production was not significantly different between treatments (Table 4). We combined this production with the measured densities of the different seagrass species to determine NAPP in the different treatments over time. The leaf loss rate $(L)$ pattern in the Tripneustes treatment was similar to that for the aboveground biomass 
Table 3. Thalassia hemprichii, Halodule uninervis, and Cymodocea rotundata. Mean \pm SE nitrogen and carbon concentrations (\% dry weight) of the seagrass aboveground biomass measured in the control and Tripneustes treatments at the end of the experiment. Significant differences $(p>0.05)$ between treatments are indicated by different superscripts (independent $t$-test; $\mathrm{n}=8$ )

\begin{tabular}{|lrrrr|}
\hline \multirow{2}{*}{ Taxon } & \multicolumn{2}{c}{$\%$ N } & \multicolumn{2}{c|}{ \% C } \\
& Control & Tripneustes & Control Tripneustes \\
\hline T. hemprichii & $2.25 \pm 0.05$ & $2.36 \pm 0.11$ & $34.5 \pm 0.2$ & $34.4 \pm 0.3$ \\
H. uninervis & $1.56^{\mathrm{a}} \pm 0.03$ & $2.19^{\mathrm{b}} \pm 0.07$ & $35.8 \pm 0.3$ & $35.8 \pm 0.3$ \\
C. rotundata & $1.89^{\mathrm{a}} \pm 0.01$ & $2.37^{\mathrm{b}} \pm 0.07$ & $38.5 \pm 0.3$ & $37.8 \pm 0.4$ \\
\hline
\end{tabular}

Table 4. Thalassia hemprichii, Halodule uninervis, and $\mathrm{Cy}$ modocea rotundata. Mean \pm SE leaf production per shoot $\left(\mathrm{mg}\right.$ shoot $\left.^{-1} \mathrm{~d}^{-1}\right)$ measured for the different seagrass species at the end of the enclosure experiment using the leaf marking technique. There were no significant differences (independent $t$-test; $\mathrm{p}>0.05)$ between treatments $(\mathrm{n}=4,10$ shoots per sample, except for $H$. uninervis $\mathrm{n}=3$ )

\begin{tabular}{|lcc|}
\hline Taxon & \multicolumn{2}{c|}{ Leaf production } \\
& Control & Tripneustes \\
\hline T. hemprichii & $2.27 \pm 0.20$ & $2.17 \pm 0.32$ \\
H. uninervis & $0.68 \pm 0.05$ & $0.43 \pm 0.12$ \\
C. rotundata & $1.16 \pm 0.22$ & $0.71 \pm 0.16$ \\
\hline
\end{tabular}

loss and was also high during the first $38 \mathrm{~d}$ (Fig. 5). $L$ declined from more than $10 \mathrm{~g} \mathrm{~m}^{-2} \mathrm{~d}^{-1}$ after introduction of Tripneustes gratilla to around $4 \mathrm{~g} \mathrm{~m}^{-2} \mathrm{~d}^{-1}$ during the last $20 \mathrm{~d}$ of the experiment.

\section{DISCUSSION}

Increased Tripneustes gratilla grazing significantly influenced seagrass species composition in the enclosures. Aboveground biomass of Thalassia hemprichii remained constant, while both Halodule uninervis and Cymodocea rotundata declined significantly due to the herbivory. The relative aboveground biomass increased significantly for $T$. hemprichii and declined significantly for $C$. rotundata during the grazing experiment. None of the seagrass species studied showed an increase in shoot density, increase in leaf production, or decline in belowground biomass in response to urchin grazing.

The change in aboveground dominance towards Thalassia hemprichii in the Tripneustes treatment could have been caused by differences in survival of the 3 seagrass species in the enclosures or a Tripneustes gratilla feeding preference for the pioneer species Cymodocea rotundata and Halodule uninervis over the climax species T. hemprichii. No decline in shoot meristem density was measured for any of the seagrasses, indicating that the meristems were not damaged by sea urchin grazing. It is therefore unlikely that the persistence of $T$. hemprichii in the Tripneustes treatment resulted from differential exposure of meristems to damage by sea urchin grazing. Overall T. gratilla grazing is beneficial for the climax species and may result in a decline of seagrass biodiversity in this meadow. A general pattern of T. gratilla grazing on different seagrass species is not clear due to contrasting results from other studies. Koike et al. (1987) reported that T. gratilla grazed predominantly on living leaves of the dominant species $T$. hemprichii rather than on leaves of Enhalus acoroides and Syringodium isoetifolium; Vaitilingon et al. (2003) showed a T. gratilla preference for $S$. isoetifolium and $H$. uninervis in a C. serulatadominated seagrass meadow in which $T$. hemprichii also occurred, while Klumpp et al. (1993) stated that T. gratilla grazed to lesser extent on $S$. isoetifolium in a $T$. hemprichii-dominated meadow. $\mathrm{N}$ concentration of the seagrass leaf material appears not to influence T. gratilla grazing, since reported values for the preferred species are often lower than those of the dominant, non-preferred species.

Increased Tripneustes gratilla grazing reduced the aboveground biomass by $74 \%$, but, in terms of total (above- + belowground) biomass, only $17 \%$ was removed. No significant effects on the belowground seagrass biomass was discerned, which is in agreement with previous research (Heck \& Valentine 1995). In the rhizomes, the plants have stored reserves, which are redistributed to leaves when necessary (Libes \& Boudouresque 1987), but these reserves are not readily accessible to most grazers (Valentine \& Duffy 2006). At

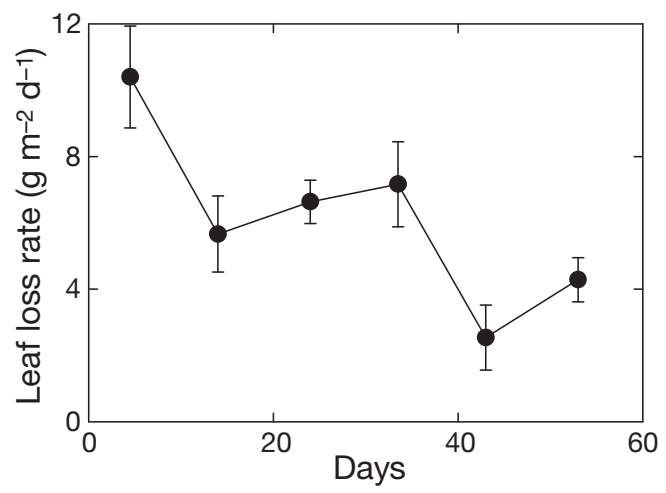

Fig. 5. Mean \pm SE $(\mathrm{n}=4)$ leaf loss rate $(L)$ in the Tripneustes treatment enclosures. The leaf loss rate was calculated as the average leaf production of 2 consecutive measurements minus the change in biomass over the same period and represented the sum of sea urchin herbivory $(H)$ rate and export of material $(E)$ 
the start, $20 \%$ of the total seagrass biomass was aboveground and available for herbivory; only $8 \%$ remained in the Tripneustes treatments at the end of the experiment. Mobilization of stored soluble carbohydrates and nutrients from rhizomes and subsequent translocation of these nutrients among physically integrated ramets (Dawes \& Lawrence 1979, Heck \& Valentine 1995) may to some extent have contributed to the maintenance of leaf production, as indicated by the significant decline of $\mathrm{C}$ concentration in Halodule uninervis rhizomes at the end of the experiment.

The fast decline in seagrass aboveground biomass in the Tripneustes grazed treatments was comparable to the decline of Thalassia testudinum aboveground biomass in Tripneustes ventricosus grazed enclosures in the Caribbean (Keller 1983). After 38 d, Tripneustes gratilla grazing resulted in short vegetation with a canopy height of about $3 \mathrm{~cm}$. Most leaves showed grazing marks and damaged tips (>90\% of leaves damaged), so we were unable to determine whether shoots produced shorter leaves. However, this indicates that a decrease in leaf length (caused by $T$. gratilla grazing) resulted in the decline of total aboveground seagrass biomass during the experiment. Since no old leaves or litter were present in the Tripneustes treatments during the last $20 \mathrm{~d}$ of the experiment, we assumed that exports $(E)$ of detached and old leaf fragments were negligible. In the absence of other grazers, this means that leaf loss rate $(L)$ was similar to the urchin herbivory rate $(H)$ from day 38 onwards. The herbivory rate of $T$. gratilla was $0.69 \pm 0.05 \mathrm{~g}$ aboveground biomass urchin ${ }^{-1} \mathrm{~d}^{-1}$. This rate is about twice the average values reported from feeding experiments (Koike et al. 1987, Klumpp et al. 1993), but within the range (0.04 to $1.1 \mathrm{~g} \mathrm{DW} \mathrm{urchin}{ }^{-1} \mathrm{~d}^{-1}$ ) reported by Koike et al. (1987).

Since Tripneustes gratilla is a generalist herbivore (Lawrence \& Agatsuma 2001), we assume it has a compensatory feeding strategy as shown for other sea urchins (Vadas 1977, Valentine \& Heck 2001). The total biomass intake of $T$. gratilla in the enclosures $\left(0.69 \pm 0.05 \mathrm{~g} \mathrm{DW} \mathrm{urchin}^{-1} \mathrm{~d}^{-1}\right)$ was multiplied by the average seagrass leaf $\mathrm{N}$ concentration $(2.3 \%)$ to calculate $\mathrm{N}$ intake rate. The value for $\mathrm{T}$. gratilla (test diameter $71 \mathrm{~mm}$ : $16 \pm 1 \mathrm{mg} \mathrm{N}$ urchin ${ }^{-1} \mathrm{~d}^{-1}$ ) in this study was comparable to that found by Koike et al. (1987) for $T$. gratilla (test diameter $72 \mathrm{~mm}$ : $13 \mathrm{mg} \mathrm{N}$ urchin ${ }^{-1} \mathrm{~d}^{-1}$ ) grazing on monospecific Thalassia hemprichii stands.

We used the principle of compensatory feeding to calculate the Tripneustes gratilla herbivory rate under natural conditions. Grazing by T. gratilla resulted in an increase in $\mathrm{N}$ concentration in the aboveground biomass caused by a relative increase in young leaf tissue, which has higher $\mathrm{N}$ concentrations (Stapel \& Hemminga 1997). In the natural meadow, the average $\mathrm{N}$ concentration of the aboveground seagrass biomass was $1.93 \pm 0.01 \%$ (J. Vonk unpubl. data), comparable to the control. Taking this difference into account, we calculated that for the same $\mathrm{N}$ intake rate as in the Tripneustes treatments, the grazing rate of T. gratilla in the natural meadow would have been $0.82 \pm 0.06 \mathrm{~g}$ leaf $\operatorname{urchin}^{-1} \mathrm{~d}^{-1}$.

The average density of Tripneustes gratilla at our research location $\left(1.55 \pm 0.07 \mathrm{~m}^{-2}\right)$ was comparable with densities found in other Indo-Pacific meadows (Klumpp et al. 1993, Alcoverro \& Mariani 2002). Combining the observed $T$. gratilla density at the research location with the estimated grazing rate under natural conditions, we calculated an urchin population consumption rate of $1.28 \mathrm{~g} \mathrm{DW}$ leaf $\mathrm{m}^{-2} \mathrm{~d}^{-1}$, corresponding to $26 \%$ of total aboveground seagrass production in this meadow. The relative amount of seagrass production removed by sea urchin grazing is strongly dependent on sea urchin densities measured. The amount of seagrass leaf material consumed by sea urchins varies between values corresponding to $1 \%$ (density 0.06 urchins $\mathrm{m}^{-2}$; Koike et al. 1987) and >100\% (40 urchins $\mathrm{m}^{-2}$; Heck \& Valentine 1995) of seagrass aboveground production. A comparable total sea urchin density, consisting of T. gratilla and 285 Salmacis sphaeroides, grazed $24 \%$ of the total aboveground production in the Philippines (Klumpp et al. 1993), comparable to our calculation.

Sea urchin grazing influences $\mathrm{N}$ cycling in seagrass meadows in different ways. Tropical meadows have high leaf production, low leaf lifespan and resorption of $\mathrm{N}$ from senescing leaves (about $15 \%$; Stapel \& Hemminga 1997) in hydrodynamically stressful environments (Koch et al. 2006). Old leaves are still photosynthetically active but become more susceptible to detachment due to mechanical stress and increased epiphyte loading. When these leaves break off from the plant, they are still buoyant and may easily be transported out of the meadow (Hemminga \& Duarte 2000). Consumption by Tripneustes gratilla prevents this leaf material from floating away.

From the $25 \mathrm{mg} \mathrm{N} \mathrm{m}^{-2} \mathrm{~d}^{-1}$ seagrass intake by Tripneustes gratilla, it is most likely that only $40 \%(9.9 \mathrm{mg}$ $\mathrm{N} \mathrm{m}^{-2} \mathrm{~d}^{-1}$ ) is actually removed and assimilated by $T$. gratilla (Koike et al. 1987), corresponding to about $10 \%$ of the net leaf $\mathrm{N}$ production $\left(87 \mathrm{mg} \mathrm{N} \mathrm{m}^{-2} \mathrm{~d}^{-1}\right.$; J. Vonk unpubl. data). Of the remaining leaf $\mathrm{N}$, half is excreted as inorganic $N$ (Koike et al. 1987), mainly ammonium (Dy \& Yap 2000, Lawrence \& Klinger 2001) and the other part are (pseudo) faeces. The average retention time of seagrass material in the guts of the sea urchin is $<2 \mathrm{~d}$, providing a quite rapid process of fragmentation of seagrass leaves as compared to mechanical fragmentation by water movements (Koike et al. 1987, Valentine \& Duffy 2006). Since the urchins 
are slow moving and the retention time in the gut is low, the faeces with negative buoyancy (authors' unpubl. obs.) are deposited close to the location of grazing.

Herbivory by Tripneustes gratilla has a significant influence on species composition of tropical mixedspecies meadows. Besides abiotic factors like hydrodynamics, light and nutrient availability, herbivory may be an important agent determining species composition and abundance in tropical meadows. Although the consumption of seagrass leaves by $T$. gratilla corresponds to $26 \%$ of the leaf production, probably only $10 \%$ is actually assimilated into urchin biomass. The remaining $\mathrm{N}$ becomes quickly available again for the meadow. This study provides support for the assumption that $T$. gratilla herbivory preserves $\mathrm{N}$ for the meadow and short-circuits and accelerates the $\mathrm{N}$ cycling of the seagrass ecosystem.

Acknowledgements. We thank J. Eygensteyn for performing the element analyses, P. Nienhuis and 2 anonymous reviewers for comments on earlier versions of the manuscript, A. Noor for administrative arrangements in Indonesia, and M. Christianen and Saido for assistance with sampling. This research was funded by NWO-WOTRO grant W86-168, Schure-Beijerinck-Popping grant SBP/JK/2005-43 and the Department of Environmental Science, Radboud University, Nijmegen.

\section{LITERATURE CITED}

Alcoverro T, Mariani S (2002) Effects of sea urchin grazing on seagrass (Thalassodendron ciliatum) beds of a Kenyan lagoon. Mar Ecol Prog Ser 226:255-263

Alcoverro T, Mariani S (2004) Patterns of fish and sea urchin grazing on tropical Indo-Pacific seagrass beds. Ecography 27:361-365

Cebrian J, Duarte CM (1998) Patterns in leaf herbivory on seagrasses. Aquat Bot 60:67-82

Dawes CJ, Lawrence JM (1979) Effects of blade removal on the proximate composition of the rhizome of the seagrass Thalassia testudinum Banks ex König. Aquat Bot 7: 255-266

Duarte CM, Cebrián J (1996) The fate of marine autotrophic production. Limnol Oceanogr 41:1758-1766

Dy DT, Yap HT (2000) Ammonium and phosphate excretion in three common echinoderms from Philippine coral reefs. J Exp Mar Biol Ecol 251:227-238

Erftemeijer PLA, Herman PMJ (1994) Seasonal changes in environmental variables, biomass, production and nutrient contents in two contrasting tropical intertidal seagrass beds in South Sulawesi, Indonesia. Oecologia 99:45-59

Goecker ME, Heck KL Jr, Valentine JF (2005) Effects of nitrogen concentrations in turtlegrass Thalassia testudinum on consumption by the bucktooth parrotfish Sparisoma radians. Mar Ecol Prog Ser 286:239-248

Heck KL, Valentine JF (1995) Sea urchin herbivory: evidence

Editorial responsibility: Kenneth Heck,

Dauphin Island, Alabama, USA for long-lasting effects in subtropical seagrass meadows. J Exp Mar Biol Ecol 189:205-217

Hemminga MA, Duarte CM (2000) Seagrass ecology. Cambridge University Press, Cambridge

Jackson JBC, Kirby MX, Berger WH, Bjorndal KA and others (2001) Historical overfishing and the recent collapse of coastal ecosystems. Science 293:629-638

Keller BD (1983) Coexistence of sea urchins in seagrass meadows: an experimental analysis of competition and predation. Ecology 64:1581-1598

Klumpp DW, Salita-Espinosa JT, Fortes MD (1993) Feeding ecology and trophic role of sea urchins in a tropical seagrass community. Aquat Bot 45:205-229

Koch EW, Ackerman JD, Verduin JJ, Van Keulen M (2006) Fluid dynamics in seagrass ecology-from molecules to ecosystems. In: Larkum AWD, Orth RJ, Duarte CM (eds) Seagrasses: biology, ecology and conservation. Springer, Dordrecht, p 193-225

Koike I, Mukai H, Nojima S (1987) The role of the sea urchin, Tripneustes gratilla (Linnaeus), in decomposition and nutrient cycling in a tropical seagrass bed. Ecol Res 2: $19-29$

Lawrence JM, Agatsuma Y (2001) The ecology of Tripneustes. In: Lawrence JM (ed) Edible sea urchins: biology and ecology. Elsevier, Amsterdam, p 395-413

Lawrence JM, Klinger TS (2001) Digestion in sea urchins. In: Lawrence JM (ed) Edible sea urchins: biology and ecology. Elsevier, Amsterdam, p 103-113

Libes M, Boudouresque CF (1987) Uptake and long-distance transport of carbon in the marine phanerogam Posidonia oceanica. Mar Ecol Prog Ser 38:177-186

Short FT, Duarte CM (2001) Methods for the measurement of seagrass growth and production. In: Coles RG (ed) Global seagrass research methods. Elsevier, Amsterdam, p 155-182

Sokal RR, Rohlf FJ (1995) Biometry, 3rd edn. W.H. Freeman, New York

Stapel J, Hemminga MA (1997) Nutrient resorption from seagrass leaves. Mar Biol 128:197-206

Vadas RL (1977) Preferential feeding: optimization strategy in sea urchins. Ecol Monogr 47:337-371

Vaitilingon D, Rasolofonirina R, Jangoux M (2003) Feeding preferences, seasonal gut repletion indices, and diel feeding patterns of the sea urchin Tripneustes gratilla (Echinodermata: Echinoidea) on a coastal habitat off Toliara (Madagascar). Mar Biol 143:451-458

Valentine JF, Duffy JE (2006) Grazing in seagrass ecosystems. In: Larkum AWD, Orth RJ, Duarte CM (eds) Seagrasses: biology, ecology and conservation. Springer, Dordrecht, p 463-501

Valentine JF, Heck KL (1991) The role of sea urchin grazing in regulating subtropical seagrass meadows: evidence from field manipulations in the northern Gulf of Mexico. J Exp Mar Biol Ecol 154:215-230

Valentine JF, Heck KL (2001) The role of leaf nitrogen content in determining turtlegrass (Thalassia testudinum) grazing by a generalized herbivore in the northeastern Gulf of Mexico. J Exp Mar Biol Ecol 258:65-86

Valentine JF, Heck KL, Busby J, Webb D (1997) Experimental evidence that herbivory increases shoot density and productivity in a subtropical turtlegrass (Thalassia testudinum) meadow. Oecologia 112:193-200

Submitted: October 2, 2006; Accepted: November 30, 2007

Proofs received from author(s): May 8, 2008 